\title{
HUBUNGAN SIFAT SINERGIS HARA N - P DAN PENGARUHNYA TERHADAP KADAR HARA DAUN BIBIT KELAPA SAWIT (Elaeis Guinensis Jacq)
}

\author{
The Relationship of Synergic Properties of Hara $N$ - P and its Effect on the Nutritional Leaves \\ of Palm Oil Seeds (Elaeis Guinensis Jacq) \\ Mardiana Wahyuni ${ }^{1}$ dan Romualdus Manurung ${ }^{2}$ \\ 1,2 Program Studi Budidaya Perkebunan, STIPER Agrobisnis Perkebunan, Jl.Willem Iskandar, Medan, Indonesia \\ Estate, Kec.Percut Sei Tuan, Kabupaten Deli Serdang, Sumatera Utara 20226 \\ E-mail: mardiana@stipap.ac.id
}

\begin{abstract}
ABSTRAK
Keberhasilan pembibitan adalah salah satu hal yang penting dalam bisnis perkebunan kelapa sawit. Pemberian pupuk sangat bermanfaat guna meningkatkan kesuburan tanah, pertumbuhan vegetatife bibit kelapa sawit serta meningkatkan daya tahan tanaman terhadap serangan penyakit. Tujuan penelitian ini yaitu mengetahui pengaruh sinergis pupuk $\mathrm{N}-\mathrm{P}$ terhadap pertumbuhan bibit kelapa sawit serta mengetahui dosis yang optimal, dan hubungan korelasi pupuk $\mathrm{N}$ dan P. Penelitian ini menggunakan Rancangan Acak Kelompok (RAK) dengan dua faktor yaitu pupuk $\mathrm{N}$ yaitu $\mathrm{N}_{0}\left(0\right.$ gr/polybag), $\mathrm{N}_{1}(50$ gr/polybag), $\mathrm{N}_{2}$ (100 gr/polybag); pupuk $\mathrm{P}$ yaitu $\mathrm{P}_{0}\left(0 \mathrm{gr} /\right.$ polybag), $\mathrm{P}_{1}$ (50 gr/polybag), $\mathrm{P}_{2}(100$ $\mathrm{gr} /$ polybag). Hasil penelitian ini menunjukkan pemberian pupuk $\mathrm{N}$ berpengaruh sangat nyata terhadap pertumbuhan tinggi tanaman, lingkar batang, berat kering tajuk, dan berat kering akar bibit kelapa sawit. pemberian pupuk $\mathrm{P}$ berpengaruh sangat nyata terhadap tinnggi tanaman, lingkar batang dan berat kering tajuk. Pemberian tunggal terbaik adalah N1P1. Korelasi N dan P yaitu Y $=0,4622+0,3669$ dengan koefisien determinasi 0,6786 dan koefisien korelasi 0,82.
\end{abstract}

Kata Kunci: Nitrogen, Posfor, Persamaan Regresi, Korelasi

\begin{abstract}
ABTRACT
Nursery success is one of the important things in the oil palm plantation business. Fertilizer application is very useful in order to increase soil fertility, vegetative growth, of oil palm seedlings, and increase plan resistance to disease attacks. The purpose of this study is to determine the synergistic effect of fertilizer $N-P$ on the growth of oil palm seeds and find out the optimal dose and correlational relationship fertilizer $N-P$. This study used a randomized block design (RBD) with two factor namely fertilizer $N$ that is $N_{0}(0 \mathrm{gr} / \mathrm{plot}), N_{1}(50 \mathrm{gr} / \mathrm{plot}), N_{2}(100 \mathrm{gr} / \mathrm{plot})$; fertilizer $P$ that is yaitu $P_{0}(0 \mathrm{gr} / \mathrm{plot})$, $P_{1}(50 \mathrm{gr} / \mathrm{plot}), P_{2}(100 \mathrm{gr} / \mathrm{plot})$. The result of this study indicate that $N$ fertilizer application has a very significant effect on plant height growth, stem circumference, crown dry weight, and root dry weight of oil palm. Fertilizer application $P$ very significant effect on plant height,stem circumference, and crown dry weight. Best combination streatment is N1P1. Corelation N and $P$ that is $Y=0,4622 x+3,669$ with the coefocient of determination 0,6786 and coefficient corelation 0,82.
\end{abstract}

Keywords: Nitrogen, Phospores, Sinergisme Regresi, Korelasi

Diterima : 25 September 2019. Disetujui: 15 Agustus 2020 


\section{PENDAHULUAN}

Indonesia merupakan negara yang adalah salah satu komoditi perkebunan yang berperan penting dalam pembangunan nasional sebagai penghasil devisa Negara. Pengembangan komoditas kelapa sawit di Indonesia terus meningkat dari tahun ke tahun, laju pertumbuhan luas areal kelapa sawit selama 2004-2014 sebesar 7,67\% per tahun dan produktivitasnya meningkat rata-rata $11,09 \%$ per tahun (Ditjebun, 2014).

Faktor penentu produktivitas tanaman kelapa sawit adalah dengan menggunakan bibit unggul secara genetik dan pemeliharaan yang baik, terutama pemupukan (Noviza, 2002). Pemupukan memberikan kontribusi meningkatnya kesuburan tanah yang menyebabkan tingkat produksi tanaman menjadi relatif stabil serta meningkatkan daya tahan tanaman terhadap serangan penyakit dan pengaruh iklim yang tidak menguntungkan. (Rahmadaini dan Wachjar, 2014 dan Adnan dkk, 2015).

Menurut Lingga (2002) bahwa ketersediaan unsur hara makro $\mathrm{N}, \mathrm{P}, \mathrm{K}$ dan $\mathrm{Mg}$ sangat penting diperhatikan untuk mencapai pertumbuhan dan produktifitas yang baik. peran utama Nitrogen bagi tanaman ialah untuk merangsang pertumbuhan tanaman secara keseluruhan, khususnya batang, cabang, dan daun. Nitrogen juga berperan penting dalam hal pembentukan hijau daun yang berguna dalam proses fotosintesis, membentuk protein, lemak, dan berbagai persenyawaan organik lainnya. Tanah yang kekurangan unsur hara $\mathrm{P}$ (fospor) akan menunjukkan gejala defisiensi yaitu warna daun seluruhnya berubah menjadi kelewat tua, dan mengkilap kemerahan, pada tepi daun, cabang, dan batang terdapat warna merah ungu yang lambat-laun berubah menjadi coklat kekuningan (Lingga, 2018).
Unsur nitrogen dan posfor merupakan dua unsur hara makro yang bersinergis, kedua unsur hara mempunyai hubungan yang koorperatif, dan mutualistik (Sudradjat dkk, 2014).

Pemupukan berimbang berarti memberikan pupuk dengan jenis dan dosis pupuk yang sesuai dengan karakteristik tanah, kebutuhan hara, dan hubungan antara unsur hara. Sifat sinergis unsur $\mathrm{N}$ dan $\mathrm{P}$ berarti serapan unsur hara $\mathrm{N}$ akan meningkat apabila unsur hara $\mathrm{P}$ dalam tanah cukup dsn sebaliknya (Kasno dkk, 2017).

Penelitian ini bertujuan untuk mengetahui hubungan sinergisme unsur hara $\mathrm{N}$ dan $\mathrm{P}$ serta pengaruhnya terhadap kadar hara $\mathrm{N}$ - P daun pada bibit kelapa sawit.

\section{METODE PENELITIAN}

Penelitian ini dilakukan di areal penelitian Kampus STIPAP Medan Sumatera Utara. Bahan yang digunakan adalah bibit kelapa sawit Varietas D x P PPKS, pupuk Urea, pupuk TSP, bambu, paranet, mulsa, seng putih, gembor, dan bahan penunjang lainnya.

Rancangan penelitian ini adalah RAK (Rancangan Ancak Kelompok) dengan dua faktor. Faktor pertama adalah dosis pupuk Urea dan faktor kedua adalah dosis pupuk TSP dengan susunan taraf sebagai berikut:

Faktor 1 pupuk N (Urea) dengan 3 taraf perlakuan :

N0 : $0 \mathrm{~g} / 2$ bibit (sebagai kontrol)

$\mathrm{N} 1: 5 \mathrm{~g} / \mathrm{bibit} / 2 \mathrm{minggu}$; selama $10 \mathrm{x}$ aplikasi, total $50 \mathrm{~g} / \mathrm{bibit}$

N2 : $10 \mathrm{~g} / \mathrm{bibit} / 2$ minggu ; selama $10 \mathrm{x}$ aplikasi, total $100 \mathrm{~g} / \mathrm{bibit}$

Faktor 2 perlakuan pupuk $\mathrm{P}$ (TSP) dengan 3 taraf perlakuan yaitu :

P0 : $0 \mathrm{~g} / 2$ bibit (sebagai kontrol) 
$\mathrm{P} 1$ : $5 \mathrm{~g} / \mathrm{bibit} / 2$ minggu ; selama $10 \mathrm{x}$ aplikasi, total $50 \mathrm{~g} / \mathrm{bibit}$

P2 : $10 \mathrm{~g} / \mathrm{bibit} / 2$ minggu ; selama $10 \mathrm{x}$ aplikasi, total $100 \mathrm{~g} / \mathrm{bibit}$.

\section{HASIL DAN PEMBAHASAN}

\section{Tinggi Bibit Kelapa Sawit}

Hasil pengamatan rata-rata tinggi bibit kelapa sawit dari 1 - 20 minggu setelah tanam (MST) terdapat pada Tabel 1.

Tabel 1. Rekapitulasi Tinggi Bibit Kelapa Sawit

\begin{tabular}{|c|c|c|c|c|c|c|c|c|c|c|c|c|}
\hline Perlakuan & \multicolumn{2}{|c|}{$1 \mathrm{MST}$} & \multicolumn{2}{|c|}{4 MST } & \multicolumn{2}{|c|}{$8 \mathrm{MST}$} & \multicolumn{2}{|c|}{$12 \mathrm{MST}$} & \multicolumn{2}{|c|}{$16 \mathrm{MST}$} & \multicolumn{2}{|c|}{$20 \mathrm{MST}$} \\
\hline NOPO & \multicolumn{2}{|c|}{39,75} & \multicolumn{2}{|c|}{40,98} & \multicolumn{2}{|c|}{42,40} & \multicolumn{2}{|c|}{44,45} & \multicolumn{2}{|c|}{45,80} & \multicolumn{2}{|c|}{47,75} \\
\hline NOP1 & \multicolumn{2}{|c|}{41,20} & \multicolumn{2}{|c|}{41,93} & \multicolumn{2}{|c|}{44,20} & \multicolumn{2}{|c|}{47,33} & \multicolumn{2}{|c|}{49,10} & \multicolumn{2}{|c|}{58,63} \\
\hline NOP2 & \multicolumn{2}{|c|}{43,43} & \multicolumn{2}{|c|}{44,98} & \multicolumn{2}{|c|}{47,35} & \multicolumn{2}{|c|}{49,20} & \multicolumn{2}{|c|}{51,53} & \multicolumn{2}{|c|}{59,20} \\
\hline N1P0 & \multicolumn{2}{|c|}{45,05} & \multicolumn{2}{|c|}{44,08} & \multicolumn{2}{|c|}{47,55} & \multicolumn{2}{|c|}{49,00} & \multicolumn{2}{|c|}{51,35} & \multicolumn{2}{|c|}{64,08} \\
\hline N1P1 & \multicolumn{2}{|c|}{42,18} & & 4,15 & 48 & 05 & & 3,00 & &, 55 & & 3,05 \\
\hline N1P2 & 43 & 75 & & 5,48 & 47 & ,73 & & 1,08 & & 60 & 71 &, 55 \\
\hline N2PO & 39 & ,78 & & 1,38 & 42 & ,78 & & 1,80 & & ,98 & &, 28 \\
\hline N2P1 & 48 & 45 & & 3,10 & 50 &, 25 & & 1,40 & & 03 & & 65 \\
\hline N2P2 & & 88 & & 1,23 & 44 & 18 & & 1,88 & & 68 & & 50 \\
\hline Rataan & 4 & 2,5 & & 3,6 & 46 & 5,1 & & 8,3 & &, 7 & 60 &, 08 \\
\hline+ & & 0 & & 1,1 & 2 & 5 & & 2,3 & & 4 & &, 3 \\
\hline Tunggal & & Indeks & & Indeks & & Indeks & & Indekss & & Indeks & & Indeks \\
\hline NO & 41,46 & 100 & 42,63 & 100 & 44,65 & 100 & 46,99 & 100 & 48,81 & 100 & 55,19 & 100 \\
\hline N1 & 43,66 & 105 & 44,57 & 105 & 47,78 & 107 & 51,03 & 109 & 54,50 & 112 & 69,56 & 126 \\
\hline N2 & 42,37 & 102 & 43,57 & 102 & 45,73 & 102 & 47,07 & 100 & 48,89 & 100 & 55,48 & 101 \\
\hline Po & 41,53 & 100 & 42,14 & 100 & 44,24 & 100 & 46,08 & 100 & 48,38 & 100 & 54,03 & 100 \\
\hline P1 & 43,94 & 106 & 44,73 & 106 & 47,50 & 107 & 50,58 & 110 & 52,56 & 109 & 63,78 & 118 \\
\hline P2 & 42,0 & 101 & 43,89 & 104 & 46,62 & 105 & 48,38 & 105 & 51,27 & 106 & 62,42 & 116 \\
\hline Uji F & F hit & & F hit & & F hit & & F hit & & F hit & & F hit & \\
\hline $\mathbf{N}$ & $0,89 \mathrm{tn}$ & & 0,64 & & $1,78 \mathrm{tn}$ & & 4,37 & & 8,96 & & 28,36 & \\
\hline $\mathbf{P}$ & 1,19 & & 1,19 & & $1,95 \mathrm{tn}$ & & 4,10 & & 3,86 & & $11,70 *$ & \\
\hline$N \times P$ & 3,47 & & 1,73 & & $1,64 \mathrm{tn}$ & & 1,21 & & 1,40 & & 0,28 & \\
\hline
\end{tabular}

Keterangan : Satuan $=\mathrm{cm} ;$ tn $=$ tidak nyata $; *=$ nyata $; * *=$ sangat nyata $;$ MST $=$ minggu setelah tanam

Perlakuan aplikasi pupuk Urea $(\mathrm{N})$ berpengaruh sangat nyata terhadap pertumbuhan tinggi bibit kelapa sawit mulai dari 12 MST - 20 MST. Tinggi bibit maksimum terdapat pada perlakuan tunggal N1 yaitu $69,56 \mathrm{~cm}$. Sesuai dengan pernyataan Hindersah dan Simarmata (2004) menyatakan bahwa unsur nitrogen sangat penting pada saat pertumbuhan tanaman, karena unsur nitrogen berperan dalam seluruh proses biokimia tanaman. Lingga (2002), mengemukakan
Nitrogen berperan untuk merangsang pertumbuhan tanaman secara keseluruhan, khususnya pertumbuhan tinggi, batang, cabang dan daun.

Perlakuan aplikasi pupuk TSP (P) memberikan pengaruh nyata dan sangat nyata pada pengamatan 12 MST, 20 MST. Peningkatan pertumbuhan tinggi bibit terbesar terdapat pada perlakuan tunggal P1 yaitu 63,78 $\mathrm{cm}$ dengan indeks $118 \%$ meningkat $18 \%$ 
dibandingkan kontrol P0. Shaeen (2007) mengatakan fosfor berperan dalam meningkatkan perkembangan akar dan sebagai sumber energi dengan membentuk ATP. Fosfor merupakan komponen utama asam nukleat yang berperan terhadap pembelahan sel pada titik tumbuh yang berpengaruh pada tinggi tanaman (Matana, 2015).

Kombinasi perlakuan $\mathrm{N}$ dan $\mathrm{P}$ yang menghasilkan pertumbuhan tertinggi $73,05 \mathrm{~cm}$ adalah perlakuan N1P1. Hal ini sesuai dengan pernyataan Lubis (2008) bahwa pemberian pupuk pada bibit kelapa sawit sangat jelas memberikan pengaruh terhadap pertumbuhan tinggi tanaman. Celebri, dkk (2011) mengatakan pemberian pupuk $\mathrm{N}$ dan $\mathrm{P}$ pada tanaman rumput-rumputan berpengaruh secara signifikan terhadap tinggi tanaman. Peran yang lain dari unsur hara nitrogen adalah untuk sintesis protein (Pradnyawan, dkk 2005), dan meningkatkan laju fotosintesis (Darmawan 2006).

\section{Jumlah Daun}

Hasil pengamatan jumlah daun terdapat pada Tabel 2.

Tabel 2. Rekapitulasi Jumlah Daun bibit kelapa sawit

\begin{tabular}{|c|c|c|c|c|c|c|c|c|c|c|c|c|}
\hline Perlakuan & \multicolumn{2}{|c|}{$1 \mathrm{MST}$} & \multicolumn{2}{|r|}{$4 \mathrm{MST}$} & \multicolumn{2}{|r|}{$8 \mathrm{MST}$} & \multicolumn{2}{|c|}{$12 \mathrm{MST}$} & \multicolumn{2}{|c|}{$16 \mathrm{MST}$} & \multicolumn{2}{|c|}{20 MST } \\
\hline NOPO & \multicolumn{2}{|c|}{5,75} & \multicolumn{2}{|r|}{6,75} & \multicolumn{2}{|r|}{8,25} & \multicolumn{2}{|c|}{10,00} & \multicolumn{2}{|c|}{11,00} & \multicolumn{2}{|c|}{11,25} \\
\hline NOP1 & \multicolumn{2}{|c|}{5,75} & \multicolumn{2}{|r|}{6,75} & \multicolumn{2}{|r|}{8,50} & \multicolumn{2}{|c|}{9,75} & \multicolumn{2}{|c|}{11,00} & \multicolumn{2}{|c|}{11,75} \\
\hline NOP2 & \multicolumn{2}{|c|}{5,75} & \multicolumn{2}{|r|}{6,50} & \multicolumn{2}{|r|}{8,50} & \multicolumn{2}{|c|}{9,25} & \multicolumn{2}{|c|}{10,50} & \multicolumn{2}{|c|}{11,75} \\
\hline N1P0 & \multicolumn{2}{|c|}{5,75} & \multicolumn{2}{|r|}{6,25} & \multicolumn{2}{|r|}{8,25} & \multicolumn{2}{|c|}{10,00} & \multicolumn{2}{|c|}{11,50} & \multicolumn{2}{|c|}{12,50} \\
\hline N1P1 & \multicolumn{2}{|c|}{6,00} & & 7,00 & & 9,00 & & 1,00 & & ,25 & & 3,25 \\
\hline N1P2 & &, 25 & & 6,75 & & 8,75 & &, 25 & & ,25 & & 3,00 \\
\hline N2PO & & 00 & & 7,00 & & 8,50 & &, 50 & & ,25 & & 2,50 \\
\hline N2P1 & & 25 & & 6,50 & & 8,75 & &, 00 & &, 50 & & 25 \\
\hline N2P2 & & 25 & & 6,75 & & 8,25 & & , 50 & & 25 & & 2,00 \\
\hline Rataan & & 6,0 & & 6,7 & & 8,5 & & 0,0 & & 1,4 & & 25 \\
\hline+ & & 0,0 & & 0,7 & & 1,8 & & 1,5 & & 4 & &, 9 \\
\hline Tunggal & & Indeks & & Indeks & & Indeks & & Indeks & & Indeks & & Indeks \\
\hline NO & 5,75 & 100 & 6,67 & 100 & 8,42 & 100 & 9,67 & 100 & 10,83 & 100 & 11,58 & 100 \\
\hline N1 & 6,00 & 104 & 6,67 & 100 & 8,67 & 103 & 10,42 & 108 & 12,00 & 111 & 12,92 & 112 \\
\hline N2 & 6,17 & 107 & 6,92 & 104 & 8,50 & 101 & 10,00 & 103 & 11,33 & 105 & 12,25 & 106 \\
\hline PO & 5,83 & 100 & 6,67 & 100 & 8,33 & 100 & 9,83 & 100 & 11,3 & 100 & 12,08 & 100 \\
\hline P1 & 6 & 103 & 6,75 & 101 & 8,75 & 105 & 10,25 & 104 & 11,6 & 103 & 12,42 & 103 \\
\hline P2 & 6,1 & 104 & 6,67 & 100 & 8,5 & 102 & 10 & 102 & 11,3 & 101 & 12,25 & 101 \\
\hline Uji F & F hit & & F hit & & F hit & & F hit & & F hit & & F hit & \\
\hline $\mathbf{N}$ & 1,21 & & 1,47 & & 0,58 & & 2,78 & & 5,25 & & 4,25 & \\
\hline $\mathbf{P}$ & 0,44 & & 2,52 & & 1,58 & & 0,87 & & 0,46 & & 0,27 & \\
\hline$N \times P$ & 0,16 & & 1,29 & & 0,58 & & 1,76 & & 0,51 & & 0,33 & \\
\hline
\end{tabular}

Keterangan : Satuan $=\mathrm{cm} ; \mathrm{tn}=$ tidak nyata $; *=$ nyata $; * *=$ sangat nyata $;$ MST $=$ minggu setelah tanam

Perlakuan pupuk Urea $(\mathrm{N})$ berpengaruh pengamatan 16 MST, dan 20 MST, rataan nyata terhadap pertambahan jumlah daun pada tertinggi pada pengamatan 20 MST adalah 
pada perlakuan tunggal N1 sebanyak 12,92 helai dengan indeks $112 \%$. Sutedjo dan Kartasapoetra (1991) menyatakan bahwa fungsi $\mathrm{N}$ antara lain untuk meningkatkan pertumbuhan daun. Pahan (2007) juga mengemukakan bahwa pertambahan daun kelapa sawit dipengaruhi keadaan musim dan tingkat kesuburan tanah.

Pemberian pupuk TSP (P) tidak berpengaruh nyata terhadap pertumbuhan jumlah daun, rataan jumlah daun terbanyak pada pengamatan 20 MST adalah pada perlakuan tunggal P2 sebanyak 12,42 helai. Pertambahan jumlah daun lebih dominan dipengaruhi oleh karakter genetik bahan tanam (Lubis, 2008).
Menurut Harahap (1998) menyatakan bahwa pertambahan jumlah daun ditentukan oleh sifat genetik tanaman yaitu bahwa pada tanaman kelapa sawit dihasilkan 1-2 helai daun pada setiap bulannya. Hal ini sesuai dengan pernyataan Pangaribuan (2001) bahwa jumlah daun sudah merupakan sifat genetik dan juga tergantung pada umur tanaman. Lebih lanjut oleh Pahan (2007) dan Herianto (2011) menyatakan bahwa kondisi lingkungan yang lebih sesuai umumnya dapat mempercepat laju pertumbuhan tanaman.

\section{Lingkar Batang}

Hasil Pengamatan lingkar batang terdapat pada tabel 3 .

Tabel 3. Rekapitulasi Lingkar Batang Bibit Kelapa Sawit

\begin{tabular}{|c|c|c|c|c|c|c|c|c|c|c|c|c|}
\hline Perlakuan & \multicolumn{2}{|c|}{$1 \mathrm{MST}$} & \multicolumn{2}{|c|}{$4 \mathrm{MST}$} & \multicolumn{2}{|c|}{$8 \mathrm{MST}$} & \multicolumn{2}{|c|}{$12 \mathrm{MST}$} & \multicolumn{2}{|c|}{$16 \mathrm{MST}$} & \multicolumn{2}{|c|}{20 MST } \\
\hline NOPO & \multicolumn{2}{|c|}{4,18} & \multicolumn{2}{|c|}{4,88} & \multicolumn{2}{|c|}{5,38} & \multicolumn{2}{|c|}{6,63} & \multicolumn{2}{|c|}{8,00} & \multicolumn{2}{|c|}{8,80} \\
\hline NOP1 & \multicolumn{2}{|c|}{4,30} & \multicolumn{2}{|c|}{4,95} & \multicolumn{2}{|c|}{5,73} & \multicolumn{2}{|c|}{7,13} & \multicolumn{2}{|c|}{8,90} & \multicolumn{2}{|c|}{11,93} \\
\hline NOP2 & \multicolumn{2}{|c|}{4,63} & \multicolumn{2}{|c|}{5,10} & \multicolumn{2}{|c|}{5,98} & \multicolumn{2}{|c|}{7,38} & \multicolumn{2}{|c|}{9,08} & \multicolumn{2}{|c|}{10,73} \\
\hline N1P0 & \multicolumn{2}{|c|}{4,25} & \multicolumn{2}{|c|}{4,88} & \multicolumn{2}{|c|}{5,88} & \multicolumn{2}{|c|}{7,75} & \multicolumn{2}{|c|}{10,33} & \multicolumn{2}{|c|}{11,78} \\
\hline N1P1 & \multicolumn{2}{|c|}{4,50} & & 13 & 6 & & & 48 & 11, & & 13 & 80 \\
\hline N1P2 & & & & 80 & 6 & & & 60 & 10, & & 12 & 68 \\
\hline N2PO & 4, & & & 88 & 5, & & & 65 & 8, & & 9, & 98 \\
\hline N2P1 & 4, & & & 00 & 5, & & & 80 & 8,8 & & 10 & 45 \\
\hline N2P2 & & & & 13 & 6 & & & 85 & 8, & & 10 & 40 \\
\hline Rataan & & & &, 0 & 5 & & & ,5 & 9 , & & 11 & 17 \\
\hline+ & 0 & & &, 6 & 0 & & & 6 & 1, & & 1 & 8 \\
\hline Tunggal & & Indeks & & Indeks & & Indeks & & Indeks & & Indeks & & Indeks \\
\hline No & 4,37 & 100 & 4,98 & 100 & 5,69 & 100 & 7,04 & 100 & 8,66 & 100 & 10,48 & 100 \\
\hline $\mathrm{N} 1$ & 4,29 & 98 & 4,93 & 99 & 6,13 & 108 & 8,28 & 118 & 10,83 & 125 & 12,75 & 122 \\
\hline N2 & 4,38 & 100 & 5,00 & 101 & 5,91 & 104 & 7,10 & 101 & 8,72 & 101 & 10,28 & 81 \\
\hline PO & 4,24 & 100 & 4,88 & 100 & 5,61 & 100 & 7,01 & 100 & 8,93 & 100 & 10,18 & 100 \\
\hline P1 & 4,43 & 104 & 5,03 & 103 & 5,94 & 106 & 7,47 & 107 & 9,72 & 109 & 12,06 & 118 \\
\hline P2 & 4,4 & 103 & 5,01 & 103 & 6,18 & 110 & 7,94 & 113 & 9,56 & 107 & 11,27 & 111 \\
\hline Uji F & F hit & & F hit & & F hit & & F hit & & F hit & & F hit & \\
\hline $\mathbf{N}$ & $0,10 \mathrm{tn}$ & & $0,04 \mathrm{tn}$ & & $1,10 \mathrm{tn}$ & & $4,03 *$ & & $13,49 * *$ & & $12,03 * *$ & \\
\hline $\mathbf{P}$ & $0,52 \mathrm{tn}$ & & $0,24 \mathrm{tn}$ & & $1,87 \mathrm{tn}$ & & $1,81 \mathrm{tn}$ & & $1,55 \mathrm{tn}$ & & $5,66 * *$ & \\
\hline$N \times P$ & $0,54 \mathrm{tn}$ & & 0,22 tn & & $0,19 \mathrm{tn}$ & & $0,18 \mathrm{tn}$ & & $0,28 \mathrm{tn}$ & & $0,98 \mathrm{tn}$ & \\
\hline
\end{tabular}

Keterangan : Satuan $=\mathrm{cm} ; \mathrm{tn}=$ tidak nyata $; *=$ nyata $; * *=$ sangat nyata $;$ MST $=$ minggu setelah tanam 
Perlakuan $(\mathrm{N})$ berpengaruh nyata dan sangat nyata pada pengamatan 12 MST - 20 MST, dengan rataan tertinggi pada pengamatan 20 MST adalah perlakuan N1 yaitu $12,75 \mathrm{~cm}$, meningkat $12 \%$. Hal ini disebabkan adanya ketersediaan hara yang cukup sehingga kegiatan metabolisme dari tanaman akan meningkat sehingga terjdi pembesaran batang. Sarief (1985) menyatakan ketersediaan air dan unsur hara yang dapat diserap tanaman dengan pemberian yang cukup, merupakan salah satu faktor yang akan menambah pembesaran sel yang berpengaruh pada pertambahan lingkar batang bibit kelapa sawit.

Pemberian pupuk TSP (P) berpengaruh sangat nyata pada pengamatan 20 MST, pertumbuhan rataan lingkar batang tertinggi pada perlakuan P2 yaitu 11,27 cm meningkat $11 \%$. Perkembangan lingkar batang tanaman merupakan kemampuan tanaman untuk menyimpan cadangan makanan pada batang. Cadangan makanan yang tersimpan dengan baik menyebabkan tanaman memiliki lingkar batang yang lebih besar yang diperoleh dari peran akar yang berkembang. (Abdurachman, 2008).

Interaksi perlakuan $\mathrm{N}$ dan $\mathrm{P}$ tidak memberikan pengaruh yang nyata terhadap pertumbuhan lingkar batang, kombinasi perlakuan yang memberikan kontribusi terbaik pada pertumbuhan lingkar batang adalah N1P1 yaitu $13,80 \mathrm{~cm}$.

\section{Kadar Hara N dan P}

Hasil analisa kadar hara $\mathrm{N}$ dan $\mathrm{P}$ terdapat pada tabel 4.

Tabel 4. Kadar Hara Nitrogen dan Kadar Hara Fosfor bibit kelapa sawit (\%)

\begin{tabular}{ccccc}
\hline Perlakuan & N total & kategori & P total & kategori \\
\hline N0P0 & 2,27 & $\mathrm{~S}$ & 1,30 & $\mathrm{ST}$ \\
N0P1 & 3,33 & $\mathrm{~T}$ & 1,86 & $\mathrm{ST}$ \\
N0P2 & 2,95 & $\mathrm{~S}$ & 1,76 & $\mathrm{ST}$ \\
N1P0 & 2,86 & $\mathrm{~S}$ & 1,59 & $\mathrm{ST}$ \\
N1P1 & 3,10 & $\mathrm{~T}$ & 1,80 & $\mathrm{ST}$ \\
N1P2 & 3,40 & $\mathrm{~T}$ & 1,92 & $\mathrm{ST}$ \\
N2P0 & 3,24 & $\mathrm{~T}$ & 1,90 & $\mathrm{ST}$ \\
N2P1 & 2,68 & $\mathrm{~S}$ & 1,87 & $\mathrm{ST}$ \\
N2P2 & 2,97 & $\mathrm{~S}$ & 1,69 & $\mathrm{ST}$ \\
Rataan & 2,98 & & 1,74 & \\
Tunggal & & Indeks $\%$ & & Indeks \\
N0 & 2,85 & 100 & 1,64 & 100 \\
N1 & 3,12 & 109 & 1,77 & 108 \\
N2 & 2,96 & 104 & 1,82 & 111 \\
P0 & 2,79 & 100 & 1,60 & 100 \\
P1 & 3,04 & 109 & 1,84 & 115 \\
P2 & 3,11 & 111 & 1,79 & 112 \\
\hline
\end{tabular}

Keterangan ; S (sedang), T (tinggi), ST (sangat tinggi) 
Rataan kadar N pada perlakuan pupuk Urea meningkatkan kadar N 9\% pada perlakuan N1. Pada perlakuan P1 kadar N mengikat. Pola/hubungan saling mengikat juga terdapat pada kadar $\mathrm{P}$ daun yaitu mengikat 8$11 \%$ pada perlakuan $\mathrm{N}$ dan $12-15 \%$ pada perlakuan $\mathrm{P}$.
Hubungan kadar $\mathrm{N}$ dan $\mathrm{P}$ pada tiap-tiap perlakuan dievaluasi dengan teknik regresi linier (Gambar 1).

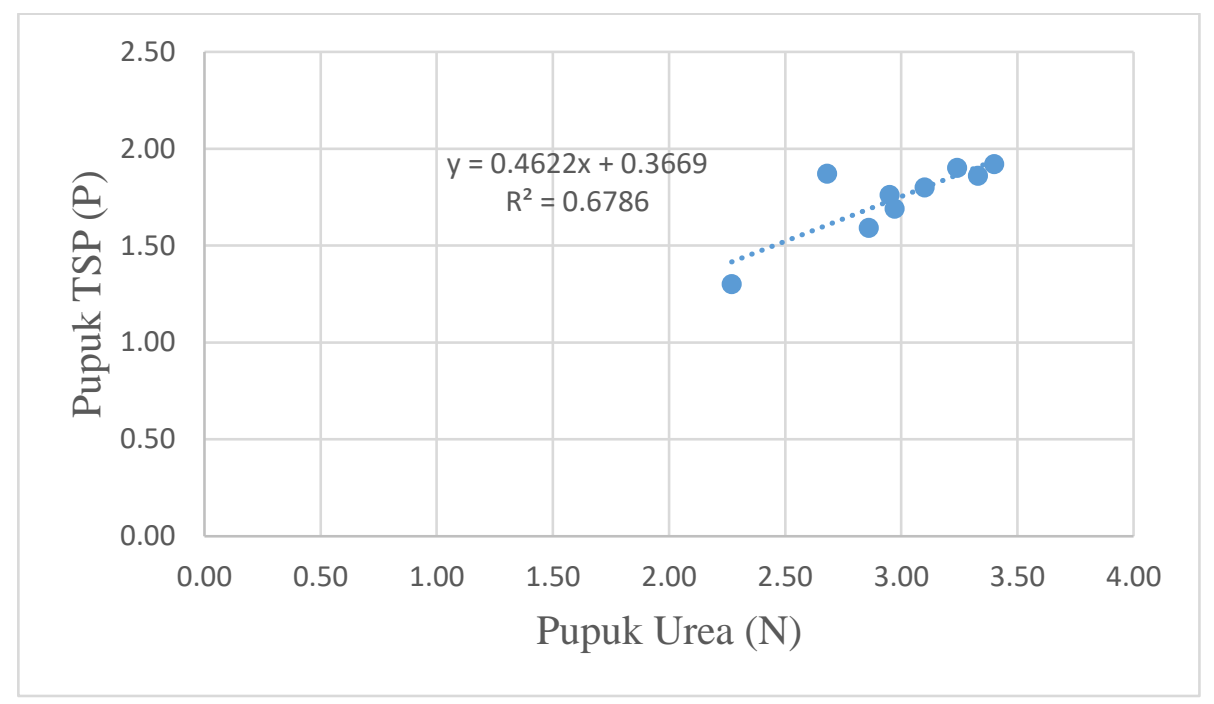

Gambar 1 Hubungan Regresi Linier Sinergisme unsur N dan P

Hubungan kadar hara $\mathrm{N}$ dan $\mathrm{P}$ dari persamaan regresi adalah $\mathrm{Y}=0,4622 \mathrm{x}+$ 0,3669 dengan koefisien determinasi atau penentuan $\left(\mathrm{R}^{2}=0,6786\right)$ atau $67,86 \%$. Faktor penentu atau keterkaitannya adalah $67,86 \%$, sedangkan $\pm 32 \%$ ditentukan oleh faktor-faktor yang lain dan koefisien korelasinya $(\mathrm{R}=$ 0,8237 ) atau $82,37 \%$ yang berarti hubungan kadar hara $\mathrm{N}$ dan $\mathrm{P}$ saling berpengaruh sebesar $82,37 \%$ yang dapat dikatakan saling mempengaruhi secara umum, sifat sinergis antar 2 faktor unsur hara yang erat adalah $>80 \%$. Dengan demikian pada perlakuan penelitian ini unsur $\mathrm{N}$ dan hara $\mathrm{P}$ saling mempengaruhi sebesar $82,37 \%$ dalam kategori sangat baik.

\section{KESIMPULAN}

Dari hasil pengamatan dapat disimpulkan sebagai berikut :

a) Perlakuan tunggal $\mathrm{N}$ (urea) berpengaruh sangat nyata terhadap pertumbuhan tinngi tanaman, jumlah daun, dan lingkar batang.

b) Perlakuan tunggal pupuk $\mathrm{P}$ (TSP) berpengaruh sangat nyata terhadap tinggi tanaman dan lingkar batang.

c) Interaksi perlakuan $\mathrm{N}$ dan $\mathrm{P}$ tidak berpengaruh nyata terhadap parameter pengamatan. Secara umum perlakuan terbaik adalah N1P1.

d) Hubungan hara $\mathrm{N}$ dan $\mathrm{P}$ saling mempengaruhi dengan persamaan $\mathrm{Y}=$ $0,4622 x+0,3669$, koefisien determinasi $67,86 \%$ dan keeratan hubungannya nyata dengan koefisien korelasi 82,37\%. 
DAFTAR PUSTAKA

Abdurachman, Adimihardja, Ai Dariah, dan Anny Mulyani. "Strategi dan teknologi pengelolaan lahan kering mendukung pengadaan pangan nasional." Jurnal Litbang Pertanian 27.2 (2008): 43-49.

Adnan, Indah Safitri, Bambang Utoyo, and Any Kusumastuti. "Pengaruh pupuk NPK dan pupuk organik terhadap pertumbuhan bibit kelapa sawit (Elaeis guineensis Jacq.) di Main Nursery." Jurnal Agro Industri Perkebunan 3.2 (2015): 69-81.

Direktorat Jendral Perkebunan. 2013. Perkembangan Perkebunan Kelapa Sawit di Indonesia. Workshop Sustainability Indicator Asessmen for Palm Oil Biodiesel. Bogor 12 April 2012.

Harianto,Heri. 2011. Budidaya Kelapa Sawit (Elaeis quinensis Jack). Citra Media Publishing. Yogyakarta .

Kasno, Antonius, and L. Anggria. "Peningkatan Pertumbuhan Kelapa Sawit Di Pembibitan Dengan Pemupukan Npk/Increasing Growth of Oil Palm Seedling with Npk Fertilization." Jurnal Penelitian Tanaman Industri 22.3 (2017): 107114.

Lingga. 2002. Petunjuk Penggunaan Pupuk. Penebar Swadaya. Jakarta.
Lingga. 2018. Petunjuk Penggunaan Pupuk. Penebar Swadaya. Jakarta.

Matana, M. 2015. Respons Pemupukan N, P, K dan Mg Terhadap Kandungan Unsur Hara Tanah dan Daun pada Tanaman Muda Kelapa Sawit. Jurnal Palma Vol 16: 23-31. 1 Juni 2015. Balai Penelitian Tanaman Palma.

Novizan, 2002. Petunjuk Pemupukan Yang Efektif. PT. Agromedia Pustaka. Jakarta.

Ramadhaini, R.Z., dan A. Wachjar. "Optimasi dosis pupuk majemuk NPK dan kalsium pada bibit kelapa sawit (Elaeis guineensis Jacq.) di pembibitan utama." Jurnal Agronomi Indonesia (Indonesian Journal of Agronomy) 42.1 (2014).

Sudradjat, Sudradjat, Anita Darwis, and Ade Wachjar. "Optimasi Dosis Pupuk Nitrogen dan Fosfor pada Bibit Kelapa Sawit (Elaeis Guineensis Jacq.) di Pembibitan Utama." Indonesian Journal of Agronomy 42.3 (2014).

Sulistyo DH, Bambang dkk. 2010. Budidaya Kelapa Sawit. PT. Balai Pustaka, (Persero). Jakarta.

Sunarko,2014. Budidaya Kelapa Sawit di Berbagai Jenis Lahan. PT Agromedia Pustaka. Jakarta Selatan. Tim Bina Karya Tani.2009. Tanaman Kelapa Sawit. Cv. Yrama Widya. Bandung. 